\title{
Ponderation of the Research of the Construction Mechanism and Development Mode of High-Level, Privately-Owned Universities
}

\author{
Bo LU ${ }^{1 a}$ and Chang-Ming LIU $2 \mathrm{~b}$ \\ ${ }^{12}$ Yangtze University College of Engineering and Technology.Jingzhou434020China \\ a249035829@qq.com \\ b945765374@qq.com
}

Key words: High level; Private universities; Development model;Construction mechanism

\begin{abstract}
Several Opinions of the State Council on Encouraging Social Forces to Start Education and Promote the Healthy Development of Private-owned Education (Guo Fa [2016] No. 81) clearly states that "we should encourage and support the development of high-quality and characteristic private-owned schools to cultivate high quality subjects, specialties, curricula, teachers, management and overall Improve the quality of education and teaching, strive to build a group of privately-run education brands with international influence and competitiveness, and strive to cultivate a group of private educators who have ideal, realm, sentiment and responsibility. " The first draft of the Opinions on Implementation drafted by the Department of Education of Hubei Province proposed "a pilot program focusing on supporting the development of a batch of high-level private schools and supporting the reform of education, teaching, and personnel training in the field of private education." This clearly suggests that we should take the implementation of classified management as a breakthrough to innovate institutional mechanisms, improve supportive policies, strengthen standardized management, improve the quality of education, further mobilize the social forces to set up education initiative, and promote the sustainable development of private education, to create a group with International influence and competitiveness of high-level private universities, which is a major task of China's higher education reform and development, but also the healthy and rapid development of private colleges and universities historic opportunity. Therefore, we must attach importance to and strengthen the research on the construction mechanism of high-level private universities.
\end{abstract}

\section{First, the High Level of Private University Construction Mechanism and Development Model of the Scope of the Study}

The research on the construction mechanism and development model of high-level private universities is limited to the following ranges: High-level private universities: High-level universities are universally acknowledged schools with some comparative advantage. Based on the concept of perspective, the nature of high-level university is characterized by comparative, fuzziness, spirituality and constructive dimensions. From the perspective of the entity, the essential characteristics of the high-level university are divided into spiritual, institutional and technical layers A level. The conceptual and physical characteristics of high-level universities are identical. Private universities refer to non-governmental organizations and individuals that use nonfinancial education funds to run and manage self-operatedly oriented higher education institutions that provide selective education. High-level private universities should be private universities with the characteristics of a high level of universities.

Construction Mechanisms: A mechanism is the process and method by which an organization or part of a work system interacts. The establishment of mechanisms, one by the system, two rely on the system. Through the corresponding establishment of the system and system, the mechanism can be reflected in practice. The construction mechanism aims to achieve the goal of 
transforming the operating mechanism of a university through the reform of the system and system of the university. That is to say, through the establishment of an appropriate system and system, a corresponding mechanism for the construction of a university can be formed.

Development model: Development model is the development direction of a private university in a country or a region under the background of its unique history, economy and culture, as well as its characteristics in terms of system, structure, thinking and behavior. Various countries and regions in the process of implementing the modernization of education in the private university system, mechanism and development strategy of choice. We should learn from the development model of foreign high-level private universities and speed up the creation of China's high-level private universities.

\section{Second, the Development of Foreign High-Level Private University Track and the Basic Characteristics}

The development of modern private school began in Europe and the United States. The University of Oxford in the United Kingdom is the oldest private university in the English-speaking world and has the reputation of "the cradle of genius and prime minister" (1). Oxford University recorded teaching history dates back to about 1096 years, so far nine centuries. Before the 19th century, the traditional British concept held that education was the responsibility of parents and guardians, the private rights of citizens, that schools were run by private individuals, and that the government had no intention of intervening in education. In 1902, the British government officially recognized the law through the Balfour Act, "public schools" and "private schools". During the Second World War, the United Kingdom enacted the Education Act of 1944, which further clarified the status of private schools in the school system and the state subsidized private schools. So far, the basic concept of private education in the United Kingdom stereotypes. Private universities such as Oxford and Cambridge became the symbol of higher education in Britain. France has always maintained state control of education. From the banning of Jesuit education in 1763 to the promulgation of the Law on the Relationship between State and Private Schools in 1959, it marks a historical reconstruction of the relations between French private schools and the state. Before the independence of 1776, the United States was a British colony. The earliest immigrants came from the United Kingdom and over 90\% were Christians. Therefore, the schools in the United States, from primary schools to universities, are based on the tradition of the British private schools. Private higher education in the United States began at Harvard College, founded in Boston in 1636, and founded William and Mary College, Yale University, University of Pennsylvania, and Dartmouth College from 1693 to 1769. These private schools are under the control of the Church . The high quality of private schools has made private higher education a symbol of American education and honor. Until the War of Independence, the public education system in the United States was rapidly developed, and public and private schools went hand in hand. The ruling of the Supreme Court of the United States on Dartmouth College in 1925 led to the formation of a view of state private schools.

Under the background of economic globalization, the world privatization of education shows the characteristics of universality, contemporaneousness, diversity, direct participation of enterprises, profitability, government support, legal protection, open-mindedness, and diminished religious influence. Most high-level private universities in the world are concentrated in Europe and the United States. Highly-recognized private universities in the world include Oxford University in the United Kingdom, Cambridge University, Yale University in the United States, MIT, Princeton University, Stanford University, Cornell University, Columbia University, Harvard University and many more. What are the characteristics of the world's top high-level private university? To sum up, first, private universities in the world have unique educational concepts and development paths; second, they have sufficient funds for running schools. Such as the United States Harvard University in 2007 up to 3.2 billion in total revenue, and increased year by year, by 2012, Harvard University, the total operating costs 4.0 billion 224 million [3]. Third, high quality of teaching, cultivate a lot of outstanding talent. For example, Oxford University has trained 12 kings, 
53 presidents and prime ministers, heads of foreign governments (such as former U.S. President Clinton), nearly 40 Nobel Prize winners and a large number of famous scientists in nearly 800 years of history. Such as economist Adam Smith, philosopher Bacon, poet Shelley, writer Green, chemist Roberto Boyle, astronomer Halley and so on. 73 faculty members at the University of Cambridge won the Nobel Prize. Harvard University produced eight heads of state and 40 Nobel Prize winners. Princeton University trained 22 MacArthur Scholars Award winners, the school has 31 alumni won the Nobel Prize, more than 1,000 alumni have served as the United States Senate, Rep., Senior federal government officials and governors and state governments senior Officer. Yale University trained five state presidents and thirteen Nobel laureates.

\section{Third, The Development of China's High-Level Private Universities Research Status Quo}

As of May 2015, there are 2553 ordinary colleges and universities in China, of which 447 are privately-run colleges and 275 independently-run colleges. These two are collectively referred to as privately-run colleges and universities, totaling 721 , accounting for $28.3 \%$ of the total number of colleges and universities in our country. Private colleges and universities have become An Important Part of China's Higher Education. However, private colleges and universities in China are only the early stages of development, not to mention a high level. The theoretical research on the construction of high-level private universities is still in its infancy. Some scholars have done research on the running of high-level private universities, involving: the research on the significance of creating high-level private universities. Establishing a high-level private university is not only an important responsibility and mission of private universities, but also an inevitable choice in the face of historic opportunities. The construction of high-level private universities is an important measure to build a powerful country for higher education. It is of great significance to promote the diversification of higher education, to lead the sustainable development of private higher education and to provide experience for the transformation and development of local undergraduate colleges and universities. Research on the Problems Facing High- level Private Universities Construction. Chen Wenlian believes that at this stage, the concept of running nonprofit public schools in private universities in China is ambiguous. The strength of teachers is not strong, the discipline construction and scientific research are weak, the funds for running schools are scarce, the quality of personnel training is far from satisfactory and the structure of corporate governance is imperfect. Study on Creating Ways for High Level Non - governmental Universities. Kong Dewen pointed out that establishing a high-level private university should be based on the principle of running a school, adhere to the public welfare of running a school, expand the financing channels, actively seek broad support, build a long-term mechanism, ensure the quality of personnel training, implement strategic management, effectively avoid risks, pay attention to employment Teachers team building, improve core competitiveness. Wang Lei believes that the construction of high-level private universities must adhere to the non-profit direction of running a school, take the initiative to shoulder social responsibility, establish a modern university system, strengthen the connotation construction, building an outstanding teaching force, at the same time must have the support and protection of national policies. Zhong Binglin suggested that if private colleges and universities are to become high-level private universities, they should attach importance to the coordinated development of the school's scale, structure, quality, efficiency and speed. Although many achievements have been made, there is not enough systematic research on the construction mechanism and development model of high-level private universities.

\section{Fourth, The Value of the Research on the Construction Mechanism and Development Model of High-Level Private Universities}

The prerequisites for the research on the construction mechanism and development model of highlevel private universities are already available. China's private colleges and universities have experienced decades of development and have acquired some conditions and strength for running 
schools. They have laid the foundation for moving toward a higher-level privately-run university. Private higher education has become an important military force in China's higher education. During the march of the great powers, they can not do without the participation of private universities. The revision of the private education promotion law and the classified management of private education create a legal and policy environment for the construction and development of private higher education. The state will further increase the participation of private-run universities Higher education supports and inputs to create a more favorable environment and conditions for the construction and development of high-level private universities.

Under the background of rapid development in economy, science and technology and education in China, we should recognize the objective environment and subjective conditions faced by privately-run colleges and universities and learn from the experience of construction and development of foreign high-level private universities to clarify the historical opportunities and guiding ideology for building a civilized university with high standard in our country And basic principles, on this basis, put forward the construction mechanism and development model of highlevel private universities, it has both theoretical and practical value. First, it is conducive to a correct understanding of the strategic significance and historical status of establishing a high-level private university, and forms a public opinion environment for the entire society to support the healthy development of private colleges and universities. Second, it is conducive to a correct understanding of the objective constraints and subjective reality conditions for establishing a highlevel private university, and formulating a construction approach that suits the needs of the national economy, social development and cultural heritage and is suitable for the conditions and foundation of private universities. Third, it is helpful to further clarify the mission and strategy of establishing a high-level private university, to promote a new path for private universities to create their own, and to find new ways and characteristics to run a higher level and run a profit-making program. Fourth, it is conducive to building a high-level private university's construction mechanism and development model, which provides a reference solution for the healthy development of private higher education.

The basic contents of the research on the construction mechanism and development model of high-level private universities include at least: First, the study of the preconditions for building a high-level private university, that is, the objective demand trend of national economic, social, scientific and technological and cultural development for college personnel training, Research on the Own School Resources, Experience, Characteristics and Vision in Colleges and Universities. Second, the foreign emphasis is on the comparative study of the construction mechanism and development model of high-level private universities in the United States, which can provide reference for the construction of China's high-level private universities. Thirdly, the research on the construction mechanism of China's high-level private universities includes the management and operation mechanism, the discipline construction mechanism, the fund-raising mechanism for running schools, the construction of teaching staff, the enrollment and employment mechanism. Fourthly, the research on the development model of Chinese high-level private universities.

\section{Summary}

Building a Civilian-run University with High Level is an Important Task in Building a Power for Higher Education. The revision of the Private Education Promotion Law and the classified management of private education have created a legal and policy environment for the construction and development of private higher education. The state will further increase its support and investment in private higher education, and provide support to the construction of high-level privately-run universities And develop to create more favorable conditions and conditions. To study the development model and construction mechanism of high-level private universities and to learn from the development models and construction mechanisms of foreign high-level private universities, especially those in the United States, are the preconditions and foundations for building high-level private universities and have important 
theoretical and practical values.

\section{Acknowledgement}

Hubei Provincial Education Science Planning Key Project Funding (Project No. 2017GA050

\section{References:}

[1] Manderley University of Oxford: The Cradle of Genius and Prime Minister. http://www.dzwww.com/edu/lxym/lxzn/201211/t20121110_7662348.html.

[2] QU Heng-chang.Analysis of the Privatization of Education in the Present World. Comparative Education Research, 2001 (1): 41-47.

[3] Zhao Yanan. Harvard University research funding sources and funding management. http://www.jysj.cee.edu.cn/shenjikanwu/wenzhangjingxuan/2017-01-05/2543.html

[4] Ministry of Education announced the list of colleges and universities in China a total of 2553 ordinary colleges and universities. http://news.ifeng.com/a/20150521/43810017_0.shtml 